Research Paper

\title{
Humoral Factors From Musculoskeletal Polytrauma Patients Impair Antibacterial Responses Of Neutrophils In vitro
}

\author{
Aikaterini Stylianaki1, Barbara Stanic ${ }^{1}$, Mario Morgenstern², Geoff R. Richardsㄹ, Fintan T. Moriarty ${ }^{1}$, Keith \\ Thompson $^{1}$ \\ 1. AO Research Institute Davos, Davos, Switzerland. \\ 2. Department of Orthopaedic and Trauma Surgery, University Hospital Basel, Switzerland. \\ $\square$ Corresponding author: T. Fintan Moriarty, AO Research Institute Davos, Clavadelerstrasse 8, 7270 Davos Platz, Switzerland. Phone: +41 814142397 , E-mail: \\ fintan.moriarty@aofoundation.org \\ (c) The author(s). This is an open access article distributed under the terms of the Creative Commons Attribution License (https://creativecommons.org/licenses/by/4.0/). \\ See http://ivyspring.com/terms for full terms and conditions.
}

Received: 2019.04.02; Accepted: 2019.06.25; Published: 2019.11.07

\begin{abstract}
Polytrauma is associated with increased risk of sepsis, but the risk for implant infection is less clear. Neutrophil antibacterial responses are significantly reduced in polytrauma patients $(n=9$, ISS $\geq 15)$ for at least 5 days compared to healthy controls. Reduced neutrophil activity could influence implant infection in addition to sepsis.
\end{abstract}

Key words: polytrauma; neutrophil; antibacterial activity

\section{Introduction}

Fracture-related infections (FRI) occur when pathogens breach the protective barrier of the skin and invade the wound, which may occur during trauma, surgery or postoperatively. Incidence of trauma-related FRI varies markedly (1-30\%) depending on injury severity [1]. Furthermore, FRI is a major economic burden, with recent estimates of $\$ 61^{\prime} 000$ - \$150'972 per infected case [1] and predicted costs of treating FRI expected to exceed $\$ 1.6$ billion in the United States alone by 2020 [2]. To successfully establish an infection, any contaminating microorganisms must avoid both prophylactic antibiotic therapy and host immune defenses. Three reasons are believed to largely explain why certain patients succumb to a FRI. Firstly, contaminating bacteria can rapidly adhere to the implanted device or exposed tissues within the wound and form an antibiotic and host defense-resistant biofilm [3-5]. Secondly, there is a defect in granulocyte function in the vicinity of the implant, due to the presence of the implant, leading to an inability to phagocytose bacteria [6]. Thirdly, vascular access is often compromised by the accompanying soft tissue trauma limiting antibiotic penetration [7] and the host immune response.

Numerous studies have shown that severe trauma itself induces temporary disorders of the immune system [8-11] that involves an early activation of immune system and the development of systemic inflammatory response syndrome (SIRS) and a partially overlapping compensatory anti-inflammatory response syndrome (CARS). In the most severe cases, this response can result in an increased risk of multi-organ failure and sepsis.

The question remains if severe trauma can also influence the effector immune cells required to clear contaminating bacteria from a fracture-site requiring internal stabilization. As the early perioperative period is the critical time for seeding of the implant, any malfunction of first-responding immune cells with direct antibacterial capacity (neutrophils) would be a critical deficit in the fight against FRI. In this 
study, we sought to investigate the potential inhibitory effects of polytrauma patient sera on neutrophil function by assessing antibacterial responses of a neutrophil-like cell line exposed to polytrauma sera in vitro, and by quantifying the levels of serum-resident neutrophil-relevant immunomodulatory cytokines in vivo in the early days post-trauma.

\section{Materials}

\section{Patients}

Nine polytraumatized patients admitted to Thriassio General Hospital (Athens, Greece) were included in this study, with full approval of the local hospital ethics committee. Inclusion criteria were: adult polytraumatized patients with an Injury Severity Score (ISS) $\geq 15$; long bone fracture; aged 18-50 years. Exclusion criteria were severely compromised respiratory or circulatory function; sepsis or suspected infection upon admission to hospital. Serum samples $(10 \mathrm{ml})$ were taken upon arrival, and at 1, 3, 5, and 7 days. The median ISS of enrolled patients was 18 (range: 17-50). Control sera were provided by 10 healthy human donors. All serum samples were collected, processed and stored at $-80^{\circ} \mathrm{C}$ at Thriasso General Hospital. Serum was then transferred to ARI Davos on dry ice for subsequent experimentation.

\section{Cell culture}

The human acute myeloid leukemia cell line PLB-985 (from the German Collection of Microorganisms and Cell Cultures (DMZB)) was grown in RPMI-1640 medium containing 10\% FBS, $100 \mathrm{U} / \mathrm{ml}$ penicillin and $100 \mu \mathrm{g} / \mathrm{ml}$ streptomycin, at $37^{\circ} \mathrm{C}$ under humidified conditions and $5 \% \mathrm{CO}_{2}$. Cells were used up to passage 10 before discarding. To induce differentiation into neutrophil-like cells [12], growth medium was supplemented with $1.25 \%(\mathrm{v} / \mathrm{v})$ DMSO for 5 days before each experiment to generate differentiated PLB-985 cells (dPLB-985), as previously described [13].

\section{Assessment of phagocytic cell function}

The capacity of polytrauma sera for influencing phagocytosis was investigated using $\mathrm{pHrodo}^{\mathrm{TM}}$ Green Staphylococcus aureus BioParticles ${ }^{\mathrm{TM}}$ (ThermoFisher, Zürich, Switzerland) and dPLB-985 cells. Cells were incubated for $4 \mathrm{~h}$ with either polytrauma or control sera prior to incubation with BioParticles for a further $2 \mathrm{~h}$ period, according to the manufacturer's instructions. Intracellular fluorescence was then assessed using flow cytometric analysis with a FACS Aria III flow cytometer. Data was analysed using FlowJo software (FlowJo LLC, Oregon).
Oxidative burst capacity in dPLB-985 cells was determined using CellROX reagent (ThermoFisher). Following a $4 \mathrm{~h}$ incubation with polytrauma or control sera, dPLB-985 cells were activated with $100 \mathrm{nM}$ $\mathrm{N}$-formylmethionine-leucyl-phenylalanine (fMLP; Sigma-Aldrich, Buchs, Switzerland) for $5 \mathrm{~min}$ to induce reactive oxygen species (ROS) production, prior to incubation with CellROX reagent for a further $30 \mathrm{~min}$. Cellular fluorescence, corresponding to ROS production, was then determined by flow cytometry.

\section{Cytokine/chemokine determination}

Polytrauma and healthy donor sera were assessed for a range of cytokines and chemokines using Luminex Magnetic Bead Panel kits (Merck Millipore, Zug, Switzerland) and a Bio-Plex multiplex system (Bio-Rad), or single/multiplex assay kits (Meso Scale Diagnostics, Rockville) and a MESO QuickPlex SQ 120 imager.

\section{Statistics}

Statistical analysis was performed using GraphPad Prism software. One-way ANOVA (Kruskall-Wallis with Dunn's multiple comparisons test) was performed to compare polytrauma with healthy control values. Results are expressed as mean \pm S.D. (phagocytosis and ROS generation) or mean \pm range (cytokine quantification). P values of 0.05 or less were considered significant.

\section{Results}

Of the nine polytrauma patients included in the study, the majorities (8/9) were the result of motor vehicle accidents and the predominant long bone fracture was of the femoral diaphysis (5/9). To investigate the impact of polytrauma sera on phagocytic cell responses, a surrogate neutrophil-like cell line was used, dPLB-985 cells, to minimize the inherent variability in using freshly isolated primary neutrophils from peripheral blood. Following treatment with either healthy donor sera, or with polytrauma sera from any time-points studied (d0-5), there was no difference in the subsequent internalization of pHrodo Green-labelled S. aureus by the dPLB-985 cells (Fig. 1A).

Despite having no effect on phagocytic capacity, polytrauma sera markedly decreased fMLP-induced oxidative burst capacity in dPLB-985 cells at all time points tested, reaching significance at $d 0(p=0.047), d 3$ $(p<0.001)$ and $d 5(p<0.001)$ (Fig. 1B).

This reduction in neutrophil oxidative burst capacity was associated with profound decreases in a range of neutrophil-related markers in polytrauma sera, such as IL-8, myeloperoxidase (MPO), MMP-8 and Elastase-2 (Table 1), compared to levels in healthy 
donors. There was also a significant decrease in circulating levels of TNF $\alpha$ and a trend for increased levels of the immunoregulatory cytokine IL-10 $(\mathrm{p}=0.058)$ immediately following trauma ( $\mathrm{d} 0)$, suggestive of a transient systemic immunosuppressed environment resulting from polytraumatic injury. Consistent with this, serum levels of the pro-inflammatory chemokine MIP-1a and HSP-70 levels were significantly decreased, together with an overall trend for decreased serum IL-1a throughout the study period. Increased levels of serum IL-6 were also detected during the first 3 days following trauma but there was no change in the levels of the pro-inflammatory cytokines IL-1 $\beta$, IL-12p70, CRP, or the chemokines MIP-1 $\beta$ and IP-10 in polytrauma patients compared to healthy donors.

\section{Discussion}

Several clinical research groups have investigated the importance of humoral and cellular factors in the cascade of events subsequent to trauma, including the development of sepsis, multiple organ failure and heterotopic ossification [14]. However, there is at present a lack of of data describing the effects of systemic trauma on the risk of developing FRI after internal fracture fixation.

In this study we demonstrate that musculoskeletal polytrauma induces systemic changes in a range of mediators capable of influencing the recruitment and function of phagocytic innate immune cells such as neutrophils. These

A

\section{PHAGOCYTOSIS}

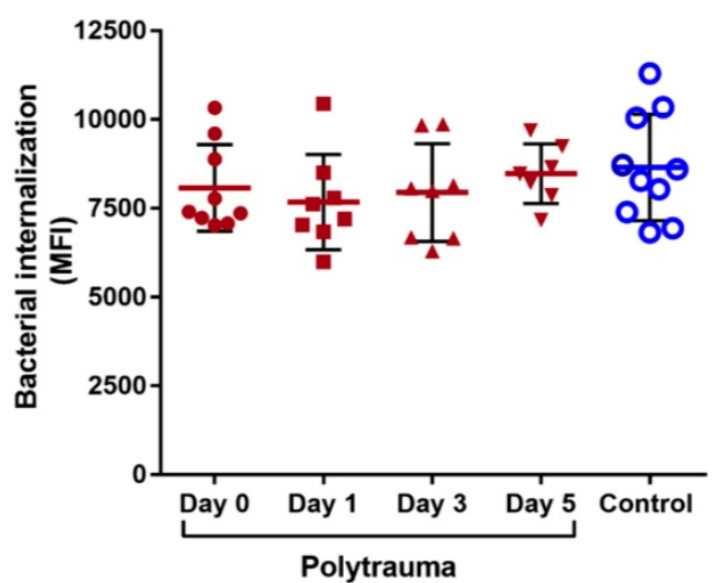

serum-resident mediators induced functional changes in a neutrophil-like cell line that, although not affecting the phagocytic capacity of these cells, did impair the respiratory burst capacity of these cells, thereby likely diminishing their ability to kill internalized bacteria. Intracellular survival of bacteria such as $S$. aureus is a recognized phenomenon in established bone infection and may also be critical in the initiation of infection. Furthermore, we observed that a variety of mediators influencing neutrophil recruitment and activity were also diminished in polytrauma serum, suggesting a potential systemic deficiency in the antibacterial capacity of neutrophils immediately following trauma.

It has been previously reported that serum from trauma patients can reduce the respiratory burst of neutrophils from healthy donors [15] although the identity of the factor(s) responsible was not confirmed, and the impact of polytrauma serum for affecting phagocytic capacity and phagosomal maturation was not determined. Consistent with this, femoral fracture patients have also been demonstrated to display functional deficits in neutrophil behavior concerning phagocytosis and antibacterial efficacy against common FRI-causative pathogens such as $S$. aureus, $S$. epidermidis and $P$. aeruginosa [16], and serum from these patients was also shown to display diminished neutrophil chemotactic properties compared to healthy donors, consistent with our findings.

B

\section{REACTIVE OXYGEN SPECIES}

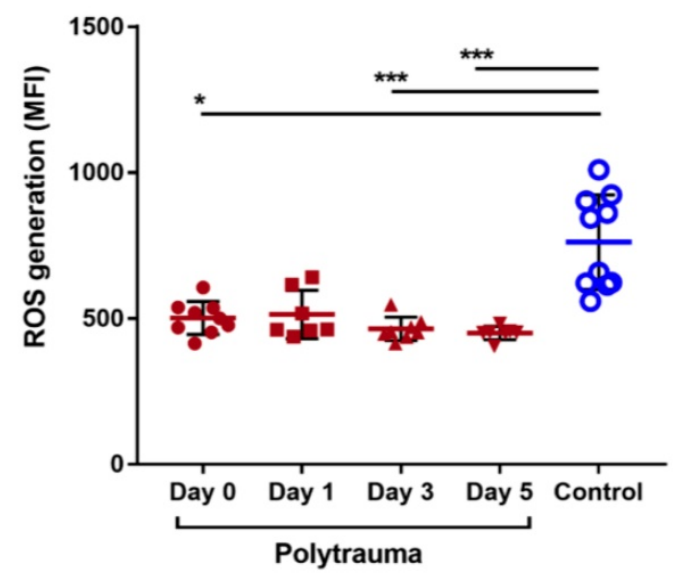

Figure 1: Effects of polytrauma patient sera on bacterial phagocytosis and generation of reactive oxygen species (ROS) by neutrophil-like cells. Differentiated PLB-985 cells (dPLB) were pre-treated with cell culture medium containing post-trauma sera or control sera (w/v=10\%) for $4 \mathrm{~h}$ prior to exposure to further stimulation, as further described: A) Phagocytosis was triggered by incubation with pHrodo Green-labelled S. aureus BioParticles for $2 \mathrm{~h}$. Internalization and acidification of the fluorophore in phagosomes results in the generation of a fluorescent signal; B) Oxidative burst was measured in dPLB cells by assessing generation of superoxide anions induced by stimulation with 100nM fMLP for 5 min, together with CellROX reagent for a further 30 min incubation. Both assays were quantified using flow cytometric analysis. (Kruskal-Wallis test, Dunn's Multiple Comparison Test, ${ }^{*} \mathrm{p}<0.05$, *** $\mathrm{p}<0.001$ ). 
Table 1: Quantification of serum-resident factors in polytrauma patients compared to healthy donor sera.

\begin{tabular}{|c|c|c|c|c|c|c|}
\hline \multirow[t]{3}{*}{ Analyte } & \multicolumn{6}{|c|}{ Analyte concentration $(\mathrm{pg} / \mathrm{ml})$} \\
\hline & \multicolumn{5}{|c|}{ Polytrauma patients } & \multirow[t]{2}{*}{ Healthy controls } \\
\hline & Day 0 & Day 1 & Day 3 & Day 5 & Day 7 & \\
\hline IL-1a & $\begin{array}{l}6.86 \\
(1.18-36.36)\end{array}$ & $\begin{array}{l}3.54 \\
(1.18-20.09)\end{array}$ & $\begin{array}{l}2.50 \\
(1.18-11.74)\end{array}$ & $\begin{array}{l}2.94 \\
(1.18-13.47)\end{array}$ & $\begin{array}{l}7.65 \\
(1.18-21.05)\end{array}$ & $\begin{array}{l}14.68 \\
(1.18-57.9)\end{array}$ \\
\hline IL-1 $\beta$ & $\begin{array}{l}0.19 \\
(0.17-0.22)\end{array}$ & $\begin{array}{l}0.52 \\
(0.13-2.85)\end{array}$ & $\begin{array}{l}0.21 \\
(0.15-0.34)\end{array}$ & $\begin{array}{l}0.20 \\
(0.17-0.21)\end{array}$ & $\begin{array}{l}0.23 \\
(0.16-0.42)\end{array}$ & $\begin{array}{l}0.62 \\
(0.17-3.31)\end{array}$ \\
\hline IL-6 & $\begin{array}{l}24.5 \\
(4.39-130.9)\end{array}$ & $\begin{array}{l}19.8^{*} \\
(4.45-51.6)\end{array}$ & $\begin{array}{l}27.3 \\
(3.88-180.0)\end{array}$ & $\begin{array}{l}9.09 \\
(2.46-17.5)\end{array}$ & $\begin{array}{l}19.6 \\
(2.44-67.0)\end{array}$ & $\begin{array}{l}5.17 \\
(0.64-18.81)\end{array}$ \\
\hline IL-10 & $\begin{array}{l}8.37^{*} \\
(0.36-44.6)\end{array}$ & $\begin{array}{l}2.15 \\
(0.32-8.61)\end{array}$ & $\begin{array}{l}1.66 \\
(0.26-9.04)\end{array}$ & $\begin{array}{l}0.64 \\
(0.31-1.42)\end{array}$ & $\begin{array}{l}1.56 \\
(0.32-5.29)\end{array}$ & $\begin{array}{l}0.75 \\
(0.23-3.05)\end{array}$ \\
\hline IL-12p70 & $\begin{array}{l}0.26 \\
(0.07-0.69)\end{array}$ & $\begin{array}{l}0.19 \\
(0.01-0.48)\end{array}$ & $\begin{array}{l}0.28 \\
(0.04-0.87)\end{array}$ & $\begin{array}{l}0.12 \\
(0.02-0.21)\end{array}$ & $\begin{array}{l}0.23 \\
(0.03-0.45)\end{array}$ & $\begin{array}{l}0.10 \\
(0.01-0.17)\end{array}$ \\
\hline TNFa & $\begin{array}{l}1.48^{*} \\
(1.07-2.12)\end{array}$ & $\begin{array}{l}2.36 \\
(1.08-5.71)\end{array}$ & $\begin{array}{l}2.61 \\
(1.76-4.77)\end{array}$ & $\begin{array}{l}2.56 \\
(1.73-4.20)\end{array}$ & $\begin{array}{l}2.74 \\
(1.59-4.42)\end{array}$ & $\begin{array}{l}3.02 \\
(0.95-6.74)\end{array}$ \\
\hline IL-8 & $\begin{array}{l}20.17 \\
(3.99-54.39)\end{array}$ & $\begin{array}{l}11.81 \\
(3.51-30.58)\end{array}$ & $\begin{array}{l}14.39 \\
(1.42-51.54)\end{array}$ & $\begin{array}{l}10.92 \\
(2.65-26.9)\end{array}$ & $\begin{array}{l}14.0 \\
(7.54-20.65)\end{array}$ & $\begin{array}{l}535.0 \\
(0.4-2500)\end{array}$ \\
\hline MIP-1a & $\begin{array}{l}3.42^{* * *} \\
(2.21-5.21)\end{array}$ & $\begin{array}{l}3.29 * * * \\
(1.58-7.64)\end{array}$ & $\begin{array}{l}4.35^{*} \\
(2.85-6.98)\end{array}$ & $\begin{array}{l}6.41 \\
(2.62-13.09)\end{array}$ & $\begin{array}{l}4.88 \\
(3.29-7.52)\end{array}$ & $\begin{array}{l}43.2 \\
(3.73-191.1)\end{array}$ \\
\hline MIP-1 $\beta$ & $\begin{array}{l}29.59 \\
(23.58-35.88)\end{array}$ & $\begin{array}{l}32.13 \\
(17.45-69.44)\end{array}$ & $\begin{array}{l}28.89 \\
(18.27-44.25)\end{array}$ & $\begin{array}{l}28.23 \\
(17.31-45.84)\end{array}$ & $\begin{array}{l}28.24 \\
(22.82-35.35)\end{array}$ & $\begin{array}{l}55.25 \\
(0.37-295.6)\end{array}$ \\
\hline IP-10 & $\begin{array}{l}21.43 \\
(6.98-43.89)\end{array}$ & $\begin{array}{l}17.16 \\
(5.39-25.85)\end{array}$ & $\begin{array}{l}51.68 \\
(18.79-196.2)\end{array}$ & $\begin{array}{l}89.13 \\
(9.24-370.1)\end{array}$ & $\begin{array}{l}60.63 \\
(8.04-153.9)\end{array}$ & $\begin{array}{l}22.35 \\
(9.44-33.06)\end{array}$ \\
\hline $\mathrm{MCP}-4$ & $\begin{array}{l}35.37 \\
(7.59-66.85)\end{array}$ & $\begin{array}{l}21.32^{* *} \\
(7.95-36.09)\end{array}$ & $\begin{array}{l}26.59 \\
(8.29-50.64)\end{array}$ & $\begin{array}{l}24.82^{*} \\
(7.95-50.66)\end{array}$ & $\begin{array}{l}37.57 \\
(21.81-55.22)\end{array}$ & $\begin{array}{l}58.95 \\
(11.13-121.9)\end{array}$ \\
\hline CRP & $\begin{array}{l}67.9 \\
(1.22-146.5)\end{array}$ & $\begin{array}{l}49.81 \\
(0.82-107.8)\end{array}$ & $\begin{array}{l}82.55 \\
(3.77-119.7)\end{array}$ & $\begin{array}{l}65.35 \\
(8.93-137.7)\end{array}$ & $\begin{array}{l}73.97 \\
(3.63-138.3)\end{array}$ & $\begin{array}{l}53.74 \\
(2.27-152.2)\end{array}$ \\
\hline MMP-8 & $\begin{array}{l}1333^{*} \\
(15.16-6099)\end{array}$ & $\begin{array}{l}956.3^{* *} \\
(15.16-3756)\end{array}$ & $\begin{array}{l}721.7^{* *} \\
(15.16-1983)\end{array}$ & $\begin{array}{l}586.2^{* *} \\
(15.16-2050)\end{array}$ & $\begin{array}{l}1028 \\
(427.5-2509)\end{array}$ & $\begin{array}{l}25029 \\
(503.3-72188)\end{array}$ \\
\hline HSP70 & $\begin{array}{l}39.76 \\
(5.11-132.3)\end{array}$ & $\begin{array}{l}15.3^{* *} \\
(2.94-26.39)\end{array}$ & $\begin{array}{l}21.43^{*} \\
(2.56-52.39)\end{array}$ & $\begin{array}{l}18.06^{* *} \\
(3.64-41.33)\end{array}$ & $\begin{array}{l}17.37^{* *} \\
(4.21-48.89)\end{array}$ & $\begin{array}{l}83.87 \\
(34.43-170.6)\end{array}$ \\
\hline Elastase-2 & $\begin{array}{l}10.17 \\
(6.5-18.58)\end{array}$ & $\begin{array}{l}9.92 \\
(6.5-13.49)\end{array}$ & $\begin{array}{l}9.02^{*} \\
(5.85-12)\end{array}$ & $\begin{array}{l}8.60^{*} \\
(5.83-12.58)\end{array}$ & $\begin{array}{l}10.18 \\
(8.05-13.09)\end{array}$ & $\begin{array}{l}22.49 \\
(8.72-65.02)\end{array}$ \\
\hline $\mathrm{MPO}$ & $\begin{array}{l}510.7 \\
(3.42-1302)\end{array}$ & $\begin{array}{l}607.2 \\
(3.99-2285)\end{array}$ & $\begin{array}{l}246.0 \\
(3.63-459.5)\end{array}$ & $\begin{array}{l}117.2^{*} \\
(2.0-279.7)\end{array}$ & $\begin{array}{l}506.5 \\
(247-1119)\end{array}$ & $\begin{array}{l}3358 \\
(2.58-13975)\end{array}$ \\
\hline
\end{tabular}

Sera from post-trauma patients or healthy donors were analysed for levels of a range of cytokines, chemokines and other neutrophil-related mediators, using multiplexed assays. Data shown are the mean values, with the range indicated within brackets. (Kruskal-Wallis test, Dunn's Multiple Comparison Test; ${ }^{*} \mathrm{p}<0.05,{ }^{* * *} \mathrm{p}<0.001$ versus healthy control values).

The specific mechanism concerning the diminished respiratory burst capacity induced by polytrauma serum is also currently unknown but may involve decreased expression of the oxidase enzyme system components p47-phox and p67-phox in neutrophils, which has been previously demonstrated in patients with burn injuries [17]. Although it is currently unknown whether a similar mechanism is responsible for the findings in our study, the observation that orthopedic surgeries, such as hip replacement surgery in elderly patients, decreases oxidative burst capacity in neutrophils [11], this is worthy of further investigation since polytrauma patients frequently require fracture fixation surgery.

\section{Outlook}

Further studies aimed at identifying the temporal nature of polytrauma-induced neutrophil dysfunction and recovery would be necessary before the clinical implications of this work can be considered. This would ideally be determined using a serum marker (or profile of markers), although this requires extensive validation in further studies with larger patient cohort sizes. In addition, the impact of polytrauma serum on primary human neutrophils would of interest, as well as of primary human macrophages, which have been associated with sepsis after internalization.

\section{Conclusion}

This study suggests that polytrauma patient sera contain factors impairing host neutrophil antibacterial efficacy through effects on ROS production, with additional possible negative effects on neutrophil recruitment and/or activity. Although our sample size is small and there are issues of patient heterogeneity, such inhibitory effects of neutrophil function may predispose polytrauma patients to an 
increased risk of FRI analogous to the established impact on sepsis.

\section{Acknowledgments}

This work was performed as part of the AOTrauma Clinical Priority Program Bone Infection.

\section{Authors Contributions}

All authors contributed to the conception and design of the study. AS, BS and KT performed experimental work and data analysis. TFM and KT wrote the manuscript. BS, MM, RGR critically revised the manuscript. All authors read and approved the final version of the manuscript.

\section{Competing Interests}

The authors have declared that no competing interest exists.

\section{References}

1. Schwarz EM, Parvizi J, Gehrke T, Aiyer A, Battenberg A, Brown SA, et al. 2018 International Consensus Meeting on Musculoskeletal Infection: Research Priorities from the General Assembly Questions. Journal of orthopaedic research : official publication of the Orthopaedic Research Society. 2019; 37: 997-1006.

2. Kurtz SM, Lau E, Watson H, Schmier JK, Parvizi J. Economic burden of periprosthetic joint infection in the United States. The Journal of arthroplasty. 2012; 27: 61-5.e1.

3. Naylor PT, Myrvik QN, Gristina A. Antibiotic resistance of biomaterial-adherent coagulase-negative and coagulase-positive staphylococci. Clin Orthop Relat Res. 1990: 126-33.

4. Stewart PS. Antimicrobial Tolerance in Biofilms. Microbiol Spectr. 2015; 3.

5. Saeed K, McLaren AC, Schwarz EM, Antoci V, Arnold WV, Chen AF, et al. 2018 international consensus meeting on musculoskeletal infection: Summary from the biofilm workgroup and consensus on biofilm related musculoskeletal infections. Journal of orthopaedic research : official publication of the Orthopaedic Research Society. 2019; 37: 1007-17.

6. Zimmerli W, Lew PD, Waldvogel FA. Pathogenesis of foreign body infection. Evidence for a local granulocyte defect. J Clin Invest. 1984; 73: 1191-200.

7. Ito K, Perren SM. Biology and biomechanics in bone healing. In: Rüedi TP, Buckley RE, Moran CG, editors. AO principles of fracture management: AO Publishing; 2007. p. 9-31.

8. Denk S, Wiegner R, Hones FM, Messerer DA, Radermacher P, Weiss M, et al. Early Detection of Junctional Adhesion Molecule-1 (JAM-1) in the Circulation after Experimental and Clinical Polytrauma. Mediators Inflamm. 2015; 2015: 463950.

9. Jukic T, Ihan A, Stubljar D. Dynamics of inflammation biomarkers C-reactive protein, leukocytes, neutrophils, and CD64 on neutrophils before and after major surgical procedures to recognize potential postoperative infection. Scand J Clin Lab Invest. 2015; 75: 500-7.

10. Lord JM, Midwinter MJ, Chen YF, Belli A, Brohi K, Kovacs EJ, et al. The systemic immune response to trauma: an overview of pathophysiology and treatment. Lancet. 2014; 384: 1455-65.

11. Sutherland AG, Cook A, Miller C, Duncan L, Yuecel R, Heys SD, et al. Older Patients Are Immunocompromised by Cytokine Depletion and Loss of Innate Immune Function After HIP Fracture Surgery. Geriatr Orthop Surg Rehabil. 2015; 6: 295-302.

12. Tucker KA, Lilly MB, Heck L, Jr., Rado TA. Characterization of a new human diploid myeloid leukemia cell line (PLB-985) with granulocytic and monocytic differentiating capacity. Blood. 1987; 70: 372-8.

13. Boulven I, Levasseur S, Marois S, Pare G, Rollet-Labelle E, Naccache PH. Class IA phosphatidylinositide 3-kinases, rather than p110 gamma, regulate formyl-methionyl-leucyl-phenylalanine-stimulated chemotaxis and superoxide production in differentiated neutrophil-like PLB-985 cells. Journal of immunology (Baltimore, Md : 1950). 2006; 176: 7621-7.

14. Cadosch D, Toffoli AM, Gautschi OP, Frey SP, Zellweger R, Skirving AP, et al. Serum after traumatic brain injury increases proliferation and supports expression of osteoblast markers in muscle cells. J Bone Joint Surg Am. 2010; 92. $645-53$

15. Lanser ME, Brown GE, Mora R, Coleman W, Siegel JH. Trauma serum suppresses superoxide production by normal neutrophils. Archives of surgery (Chicago, Ill : 1960). 1986; 121: 157-62.
16. Papadopoulos NG, Lianou PE, Lyritis GP, Papavassiliou TJ. Neutrophil functions in patients with fractures of the upper end of the femur. Calcified tissue international. 1993; 52: 415-8.

17. Rosenthal J, Thurman GW, Cusack N, Peterson VM, Malech HL, Ambruso DR Neutrophils from patients after burn injury express a deficiency of the oxidase components p47-phox and p67-phox. Blood. 1996; 88: 4321-9. 